РАФАЛЬСЬКА О.В.

\title{
ПРОЦЕСУАЛЬНА СПІВУЧАСТЬ ЯК СКЛАДОВА ЧАСТИНА МНОЖИННОСТІ В СИСТЕМІ ПРОЦЕСУАЛЬНОГО ПРАВА УКРАЇНИ
}

\begin{abstract}
У статті вивчається інститут процесуальної співучасті в адміністративному судочинстві України та тематика, присвячена актуальним питанням адміністративного процесуального права. У статті проаналізовано низку наукових підходів до визначення змісту поняття «процесуальна співучасть», досліджено його правову природу, надано його авторське формулювання. Окрему увагу приділено питанням розмежування суміжних процесуальних інститутів - процесуальної співучасті та групового позову.

У статті проведено оцінку ролі інституту множинності, досліджено закон та положення адміністративного провадження та визначено прогалини, які можна було б усунути шляхом збереження найбільш ефективних положень процесуального закону, враховуючи правові позиції, сформульовані судовою практикою, що було б відображено в перспективному єдиному кодексі адміністративного судочинства. Ця процедура сприяє забезпеченню доступу до правосуддя, виключає можливість навмисної затримки процесу, не впливаючи на процесуальні гарантії. Особлива увага приділяється проблемам, які виникають на етапі застосування цього принципу. Дослідження охоплює питання законності прийнятих рішень, випадків множинності суб'єктів як від імені позивача, так і від імені відповідача, проблеми, пов'язані з позовними вимогами.

На основі відповідної судової практики та наукової теоретичної бази було проаналізовано та систематизовано основні підходи до визначення цього поняття. Сформульовано важливий висновок, що в контексті правозастосування така ідея наповнюється якісно новим змістом, який відповідає як національній, так і міжнародній спільноті.

У статті досліджено сьогочасний стан та причини виникнення прогалин правового регулювання адміністративних відносин як одного з видів юридичних дефектів в адміністративному праві України, що знижує ефективність правового впливу.

Автором статті вивчено тенденції розвитку та сучасний погляд на адміністративне судочинство та його структуру в Україні. Зроблено висновок про відставання вказаного способу мінімізації дефектів правового регулювання від потреб практики.

Автор досліджує досвід проведення інституційних класових дій та можливість його використання в процесуальному законодавстві України, визначає особливості провадження.
\end{abstract}

Ключові слова: прочесуальне законодавство, адміністративний процес, процесуальна співучасть, адміністративне судочинство, груповий позов.

The article studies the institute of procedural complicity in administrative proceedings in Ukraine and devoted to topical issues in administrative procedural law. This paper examines a number of scientific approaches to the definition of "procedural participation" concept, investigates its legal nature, gives its author's wording. Attention is spared to questions of differentiating of contiguous procedural institutes - procedural participation and class action.

The article assesses the role of the institution of multiplicity, researched the law and the provisions of the administrative proceedings and identifies gaps that could be eliminated through the preservation of the most effective provisions of the procedure law, giv-

(C) РАФАЛЬСЬКА О.В. - аспірант кафедри адміністративного права (Київський національний університет імені Тараса Шевченка) 
en the legal positions formulated in court practice, which would be reflected in the prospective uniform code of administrative procedure. This procedure promotes to ensuring access to justice, eliminating the possibility of intentional delay in the process, without affecting the procedural guarantees. The special attention is given to the problems which arise at the stage of applying this institution. The study covers the questions of legality of the given decisions, cases of plurality of subjects both on behalf of the claimant and on behalf of the defendant, problems relating to the participation of remedial claimants.

Based on the relevant judicial practice and scientific theoretical base, the main approaches to the definition of this concept were analyzed and systematized. An important conclusion has been formulated that in the context of law enforcement, such an idea is filled with new content that corresponds to both the national and international public.

In article the current situation and the reasons of the gaps emergence in the administrative relations' legal regulation as one of legal defects in Ukrainian administrative law, that reduces the effectiveness of law influence, have been investigated.

The author of the article has studied the tendencies of development and modern view of administrative legal proceedings and its structure in Ukraine. The conclusion has been made about lag of addressing the gaps as one of the methods of legal defects minimizing from the needs of practice.

The author examines the experience of the institute class action and possibility of its use in the procedural legislation of Ukraine, defines the features of the proceedings.

Key words: procedural law, administrative process, procedural participation, administrative legal proceedings, class action.

Вступ. Дискусія щодо налагоджування інституту співучасті на європейській арені та його достеменна розробка для адміністративного судочинства в Україні, як підсумок, набуває чималого значення. Причиною для такого визначення є поведінка суб'єктів владних повноважень, що неодноразово порушувала права та інтереси великого кола осіб.

Нинішнє регулювання в адміністративному судочинстві включає неабияку кількість процесуально-правових категорій, що характеризуються неналежним, нечітким тлумаченням як із боку вітчизняної, так і сьогочасної судової практики та наукової теорії, де однією з них виступає процесуальна співучасть.

Нині у процесі вивчення ступеню досліджень науковцями та вченими-процесуалістами зазначеного інституту процесуальної співучасті як елементу множинності осіб, що залучаються до участі в судовій справі, однозначно варто констатувати його використання в господарському та цивільному процесах. Із прийняттям Кодексу адміністративного судочинства та з моменту здійснення правосуддя в адміністративних справах це розкривається у процесі аналізу та розв'язання публічно-правових спорів. Наявні ж здобутки у сфері вивчення співучасті - переважно надбання науки цивільного процесуального права, які не дають вичерпної відповіді щодо особливостей участі в адміністративному судочинстві фізичних осіб, суб'єктів владних повноважень [1].

Нормалізація та налагоджування суспільних відносин у таких сферах, як державне та соціальне управління, організація управлінських відносин, які, своєю чергою, можуть формуватись на будь-якому рівні публічної діяльності, також у галузі суспільних відносин, що утворюються під час захисту порушених прав, свобод та інтересів, забезпечуються діючою в країні системою адміністративних правових норм, що фіксуються та обгрунтовуються в належних джерелах адміністративного права.

Питання щодо вивчення процесуальної співучасті в системі адміністративного процесу для сучасної юридичної науки $є$ досить новим, необхідним концептом, який дезінтегрує недостатність зв'язків, які формують негативний ефект, що спонукає до зміни правового регулювання громадських відносин.

Постановка завдання. У наданій до розгляду статті головною метою дослідження $\epsilon$ питання, пов'язані з поняттям та сутністю інституту процесуальної співучасті в процесуальному праві України, аналізом сучасної ситуації процесуальної реалізації інституту співучасті в адміністративному процесі України. На основі відповідної судової практики та наукової теоретичної бази проаналізувати основні підходи до визначення цього поняття та сформулювати висновок, що в контексті правозастосування така ідея відповідає як національній, так і міжнародній спільноті. 
Результати дослідження. С.В. Ківалов зазначав: «У провадженнях з адміністративного судочинства особами, які мають інтерес у справі, $є$ громадяни, державні органи, органи місцевого самоврядування, державні службовці, організації, підприємства, установи, заклади незалежно від форм власності, які в адміністративному судочинстві прийнято називати сторонами» [2].

Процесуальна співучасть для будь-якої форми судового провадження видається ускладненою формою процесу. Це достеменно характеризує інститут множинності, який проявляється участю великого кола осіб на стороні позивача і/або відповідача.

Наприклад, постановою у 2018 р. Велика Палата Верховного Суду залишила без задоволення апеляційну скаргу Громадської організації «Центр протидії корупції», Громадської організації «Всеукраїнське об’ єднання «Автомайдан» та Громадської організації «Трансперенсі Інтернешнл Україна» на ухвалу Верховного Суду у складі суддів Касаційного адміністративного суду в адміністративній справі за їх позовом до Президента України Порошенка Петра Олексійовича, де треті особи: Національне антикорупційне бюро України та громадянин України, про визнання протиправним та скасування Указу Президента України [3].

Цей інститут $є$ необхідним засобом для досягнення економії та швидкого й чіткого винесення судового рішення. Варто зазначити, що важливою та першочерговою причиною участі осіб в адміністративному процесі є існування інтересу, який, своєю чергою, потребує захисту в суді у зв'язку з порушенням прав і свобод учасника матеріальних правовідносин. Саме вказаний інтерес $\epsilon$ підгрунтям для виникнення або виключення співучасті.

При процесуальній множинності предметом процесу є виникнення спірних матеріальних правовідносин, тобто колективних, а у такому разі це спричиняє формування необхідної співучасті, що зумовлюється участю всіх осіб у процесі, адже за відсутності хоча б одного стає неможливим розгляд справи по суті або ж винесення рішення щодо такого спору. За необхідної співучасті суд зобов'язаний залучити до судового провадження всіх співучасників у цій справі, тобто конкретно тих осіб, які є сторонами спору щодо матеріальних правовідносин.

Деякі вчені-процесуалісти зазначають, що на практиці $є$ чимало випадків, коли співучасть $\epsilon$ обов'язковою. Але в такому аспекті судового провадження окремий розгляд позовів $\epsilon$ неприйнятним. Відсутність залучення в таких справах на одну зі сторін співпозивачів або співвідповідачів спричиняє порушення прав та інтересів учасників адміністративного процесу і постановлення судом незаконного та неаргументованого рішення.

3 огляду на вищезазначене, неодномоментним $є$ обгрунтування з боку цивільного процесу, де законодавство з приводу цього не надає чітко та достеменно сформованого переліку випадків виникнення співучасті та засобів регулювання при застосуванні такого інституту, але при цьому необхідно зауважити, що суд не зможе винести справедливе рішення, якщо не розгляне суперечку щодо права з точки зору інтересів усіх учасників процесу.

Щодо факультативної співучасті, то вона формується за обставин, коли є наявними подібні права та обов'язки, тобто коли учасники мають аналогічну зацікавленість, яка грунтується на схожості фактів щодо спору. У такому разі суд виносить постанову щодо того, чи буде груповий розгляд справи у зв'язку з вимогами кількох позивачів або до таких відповідачів сприяти справедливому, чіткому, швидкому розгляду та вирішенню справи.

Окрім підстав, які закріплені в законодавчих актах, неодномоментним є виокремлення умов, які фаворитизують виникнення співучасті в судовому процесі.

По-перше, вагомим аспектом витупає волевиявлення осіб, тобто коли участь у справі беруть кілька суб'єктів, які наділені правом вимоги та виявляють бажання щодо участі як співпозивач.

По-друге, суд на стадії підготовки до розгляду першочергово звіряється з визначеним складом осіб у процесі та з фактами, підставами формування процесуальної співучасті. А потім, після перевірки, на першого покладаються зобов'язання ознайомити всіх учасників справи, що у провадженні суду знаходиться справа, рішення щодо якої зачіпає інтереси всіх сторін, й запропонувати висловити свою позицію щодо вступу в процес.

По-третє, неодмінно варто констатувати, що якщо поставлені завдання не виконуються в повному обсязі, це призводить до негативних наслідків, які характеризуються, наприклад, суперечливим, незаконним рішенням, адже розв'язання питань, що стосуються прав та обов'язків осіб, що не залучені до участі в справі, є конститутивним порушенням норм процесуального права, що викликає скасування рішення суду в апеляційному або ж в касаційному порядках. Але завдяки дії такого принципу, як диспозитивність, суд не має законодавчо визначених прав силувати до захисту особистих прав, саме тому до справи він має змогу залучити співвідповідача, а не співпозивача. 
У цивільному процесуальному праві дослідження практики суду демонструє, що вони не часто вдаються до об’єднання в одне провадження однорідних справ, а роз'єднують такі вимоги, що випливають із суперечок за участю одних і тих самих осіб, в окремі групи, якщо компонування справ може затягти або ускладнити рух цивільних справ [4]. Потрібно зазначити, що співучасть та об’єднання вимог у позові класифікуються як незалежні один від одного інститути процесу.

При процесуальній співучасті в рамках однієї адміністративної справи концентрується весь доказовий матеріал, який, своєю чергою, дає змогу правильно вирішити суперечку в правовідносинах, уникнути постановлення судом суперечливих рішень за вимогами кількох позивачів або до кількох відповідачів. Це також сприяє скороченню часу, способів і засобів, що нерозважливо витрачаються на розгляд судової справи, а також пришвидшує процес захисту порушеного, спірного права або ж охоронюваного законом інтересу. Б.В. Сангаджиєв зазначає, що економія розглядається в двох аспектах: 1) економія грошових коштів; 2) економія часу [5, с. 147].

Такий інститут, до речі, може виникнути за ініціативою позивача, відповідача, а в деяких випадках й зі сторони суду. Але варто констатувати, що у процесі аналізу процесуального співучасті необхідною є вагома їі ознака, яка дає змогу достеменно відрізнити співучасника від всіх інших суб'єктів процесуальних правовідносин, тобто за функціонування будь-якого ії виду взаємопов'язані або однорідні права та обов'язки співучасників не мають виключати один одного загалом або в певній зазначеній частині. Іншими словами, право на вимогу одного співпозивача має цілком відповідати праву на вимогу іншого. Кожен співучасник у судовому розгляді характеризується як самостійний, незалежний суб’єкт, який наділений правом вільного вибору способів дії в процесі незалежно від всіх інших осіб, які беруть участь на тій самій стороні.

Особливістю судового рішення при співучасті є саме те, що суд виносить одне єдине рішення, в якому зазначаються відповіді на кожну позовну вимогу, причому, якщо воно стосується одразу кількох учасників, відповідно, судом вказується, в якій частині воно стосується кожного співпозивача або що право є солідарним.

У разі постановлення рішення суду проти кількох відповідачів зазначається, в якій частині кожен із співвідповідачів зобов'язується виконати рішення, або вказується їхня спільна відповідальність. Якщо один із співпозивачів вирішує змінити предмет позовної вимоги, то він припиняє співучасть за відповідним правом у суді, адже вказаний механізм діє тільки в тих випадках, коли функціонує однотипний предмет позову, а за інших обставин така вимога розглядається в індивідуальному порядку.

3 огляду на сучасний стан законодавчого закріплення та практики, доречно констатувати, що адміністративний процес, на відміну від цивільного та господарського, характеризується проблематичністю щодо застосування та вивчення інституту процесуальної співучасті. Досить чітко простежується тенденція ускладнення відносин між суспільством та органами публічної адміністрації, що викликана інтенсивним розвитком економічного обороту, обтяження майнових й особистих немайнових відносин, що, своєю чергою, зумовлює перенасичення суб'єктного складу та юридичних зв'язків між учасниками відносин. Такі багатосуб'єктні правові відносини мають достеменно регулюватись нормами матеріального права та функціонувати в регламентованих законодавством рамках.

Висновки. Отже, процесуальна співучасть - це інститут процесуального права, який обов'язково зумовлений певними процесуальними причинами. Диференціація цього інституту на обов’язкову і факультативну пояснюється залежністю від характеру матеріальних правових зв'язків між суб'єктами спірних правовідносин. Вказане розмежування є поширеним у законодавстві зарубіжних країн.

Співучасть також є однією з найпоширеніших форм множинності осіб, що беруть участь в адміністративному процесі. Вона викликана певною чіткою наявністю багатосуб'єктного спірного матеріального правового відношення, також присутністю однієї загальної підстави, 3 якої випливає кілька спірних матеріальних правовідносин, що є предметом адміністративного судочинства, і за умови можливості задоволення вимог усіх співучасників в одному процесі.

Тому на підставі проведеного аналізу інституту процесуальної співучасті в адміністративному процесі України та ії співвідношення з іншими галузями доцільним вбачається структурування та повна регламентація цього інституту на законодавчому рівні, роз'яснення випадків процесуальної співучасті та перелік нормативних актів, які їх передбачають. Також значущим елементом $\epsilon$, по-перше, закріплення істотних ознак співучасті, що дасть змогу достеменно відмежовувати іiі від інших форм множинності осіб, які беруть участь у справі, по-друге, конкретизація порядку залучення співучасників до судової справи та пряме трактування можливостей надання суду права за власної ініціативи залучати співучасників. 


\section{Список використаних джерел:}

1. Бевзенко В.М. Інститут процесуальної співучасті в адміністративному судочинстві України: сутність та правове регулювання. Держава і право. 2010. № 47. С. 223.

2. Ківалов С.В. Понятійно-правова характеристика сторін як учасників адміністративного судочинства. Наукові праці Національного університету «Одеська юридична академія» : збірник наук. праць / редкол.: С.В. Ківалов (голов. ред.), М.В. Афанасьєва (заст. голов. ред), В.М. Дрьомін [та ін]; відп. за вип. В.М. Дрьомін; МОН України, НУ «ОЮА». Одеса : Юрид. л-ра, 2015. Т. 15. 22 с.

3. Постанова Великої Палати Верховного Суду від 18 грудня 2018 р. в справі № 9901/657/18 (П/9901/657/18). URL: http://reyestr.court.gov.ua/Review/78977396

4. Грось Л.А. Институт процессуального соучастия: связь между процессуальным и материальным правом. Российская юстициия. 1998. № 3. С. 35.

5. Сангаджиев Б.В. Особенности организационно-правового обеспечения деятельности федеральных судов общей юрисдикции Российской Федерации. Вестник РУДН. Серия: юридические науки. 2011. № 3.

УДК 346.9

DOI https://doi.org/10.32844/2618-1258.2019.6.37

РОГОВА Є.I.

\section{ХАРАКТЕРИСТИКА ПОНЯТІЙНИХ КАТЕГОРІЙ ІНФОРМАЦЙНОЇ БЕЗПЕКИ}

В умовах сучасних глобальних та регіональних інформаційних протистоянь, деструктивних комунікативних впливів, зіткнення різновекторних національних інформаційних інтересів, поширення інформаційної експансії та агресії захист національного інформаційного простору та гарантування інформаційної безпеки стають пріоритетними стратегічними завданнями сучасних держав у системі глобальних інформаційних відносин. Збереження інформаційного суверенітету, формування ефективної системи безпеки в інформаційній сфері є актуальною проблемою і для України, яка часто є об'єктом зовнішньої інформаційної експансії, маніпулятивних пропагандистських технологій та руйнівного інформаційного вторгнення. В умовах російсько-українського конфлікту захист національного інформаційного простору від негативних інформаційно-психологічних впливів, операцій та війн, гарантування інформаційної безпеки та інформаційного суверенітету набувають особливого значення і стають чинниками збереження національної ідентичності України та функціонування ії як суверенної та незалежної держави.

У світлі сучасних процесів значення інформації у суспільстві швидко зростає. Також і просування України до європейського співтовариства ставить перед нею важливе або можливо навіть і необхідне завдання - зайняття міцних позицій в усіх сферах суспільного життя, в тому числі і в інформаційній.

У сучасному світі інформація визначається як рушійна сила та домінуюча галузь, яка ставить за завдання впровадження передових інформаційних технологій в усі сфери суспільної діяльності. Тож інформаційна безпека є одним із найважливіших понять у науці і різних сферах людської діяльності. Сутність і комплексність цього поняття характеризує сучасне інформаційне суспільство. Враховуючи те, що питання інформаційної безпеки в умовах глобалізації носять гострий характер, необхідно визначити оптимальні шляхи усунення інформаційних загроз і небезпек і мінімізації впливу негативних наслідків у сфері інформаційної діяльності держави.

РОГОВА Є.І. - аспірантка кафедри адміністративного права і процесу та митної безпеки (Національний університет державної фіскальної служби України) 